\title{
Physiochochemical Properties of Honey Produced in Gozamen District, East Gojjam Zone, Amhara Region
}

\author{
Sileshi Yeserah $(\mathrm{MSc})^{1} \quad$ Abebe Jenberie $(\mathrm{PhD})^{2} \quad$ Desalegn Begna $(\mathrm{PhD})^{3}$ \\ 1.Ethiopian Meat and Dairy Industry Development Institute, \\ Department of Honey and Beeswax Processing and Research Directorte, \\ Bishoftu, Ethiopia P.O.Box:+251-1573 \\ 2.Ass. Prof., College of Agriculture and Environmental Sciences, Bahir Dar University, Ethiopia \\ 3.Ass. Prof., of animal breeding and genetics, Ambo University, Ethiopia
}

The research is financed by Ethiopian Meat and Dairy Industry Development Institute and SNV-ASPIRE Project Abstract

The study was conducted in Gozamen District, East Gojjam Zone, Amhara Region, Ethiopia, from September 2017 to July 2018 to determine honey quality produced in the area.The effects of Agro-ecological Zones (location) and hive type on honey quality in the study area were assessed.Questionnaires for the survey, laboratory analysis for honey quality were employed. A total of 120 beekeepers (118 males and 2 females) and 25 honey traders (18 males \& 7 females) were interviewed for the survey. A total of 22 honey samples (18 samples from six kebeles representing the three beehive types across the three agro-ecologies and 4 samples from market points) were collected and analyzed at Holleta Bee Research Center and Bless Agri Food Laboratory Services PLC .The survey data were analyzed using SPSS version 23. The honey quality analysis indicated that the overall mean value of moisture content $(17.22 \pm 1.56)$, glucose $(17.22 \pm 1.56)$, sucrose $(26.96 \pm 4.94), \mathrm{pH}(4.28 \pm 0.26)$ and acidity $(29.322 \pm$ $0.2)$ were significantly different among different locations at $(\mathrm{P}<0.05)$. Similarly, the mean values glucose, sucrose , ash and water-insoluble solids were significantly different at $(\mathrm{P}<0.05)$ between the three types of hives. The honey samples collected from honey traders were with high sucrose level(10.18\%) confirming the adulteration of honey with sugar syrups.As a result; inspection, control, and regulatory measures are indispensable tasks to improve the honey quality in the study area.

Keywords: Gozamen, Physicochemical properties

DOI: $10.7176 /$ FSQM/94-06

Publication date: February $29^{\text {th }} 2020$

\section{INTRODUCTION}

The natural conditions, favorable agro climatic zones and abundance of flora provide excellent conditions for beekeeping in Ethiopia.There are four commonly practiced bee husbandry in Ethiopia including migratory (transhumant), traditional, intermediate or transitional and frame hive beekeeping.Generally, it is characterized mainly by forest beekeeping in the south and southwest and also backyard beekeeping in major areas of the country (Nuru 2002).

The most important honey producing regions in Ethiopia are Oromia, Amhara, SNNPR, Benishangul-Gumuz and Tigray.More specifically, out of 47,706 tons of honey, Oromia accounts for $38 \%$ of the honey produce and over $51 \%$ of the bee colonies followed by Amhara which accounts for about $26 \%$ of the honey produce and $21 \%$ of the colonies.In Amhara regional state, about $90 \%$ of the honey is produced by six major zones.North Gonder accounting $32.8 \%$ of the honey produced is followed by East Gojjam (14.3\%), West Gojjam (13.9\%), Awi (10.2), South Wollo (9.3\%), and South Gonder (9.1\%) (CSA 2016/17).

In Amhara region,the estimated number of bee colonies managed in traditional, transitional and fram hives were $1,321,173 ; 10,555$ and 107,016 respectively producing $10894.4 ; 10.6$ and 1,341.4 tons of honey.Similarily, the number colonies in Eastern Gojjam Zone in traditional,transitional and frame hives were 165,505; 3,525 and 12,063 respectively. Correspondingly, the estimated amount of honey in traditional, transitional and frame hive were 10,894.4; 139.8 and 251.6 tons of honey (CSA 2016/17).

Physicochemical parameters (moisture, reducingsugar, sucrose, waterinsoluble, ash, free acid, hydroxymethylfurfural contents, $\mathrm{pH}$, electrical conductivity and specific rotation), sensorial and microbiological characteristics are used to determine the quality of honey. The physicochemical properties for a given honey is influenced by the nectar types that the honeybee used, geographical ecology (climatic and soil) and postharvest honey handling practices(Aberaet al .2013).

\section{Objectives of the study}

General objective

To study the honey quality in the study area and its impact on domestic and export market in Gozamen district of East Gojjam Zone, Amhara Region, Ethiopia. 


\section{Specific objectives}

* To determine the quality of representative honey samples of Gozamen District,

* To pinpoint the impacts of honey quality on domestic and export market in the study area

\section{MATERIALS AND METHODS}

\section{Description of the study area}

The study has been conducted in Gozamen district of East Gojjam Zone in Amhara National Regional State (ANRS).Gozamen district is one of the 18 districts of Eastern Gojjam Administrative Zone of Amhara National Regional state (GDLFDO 2017/18). Debre Markos is the capital of the district and it contains 25 rural-Kebeles. The district is bordered by Baso Liben in the Southeast, by Debre Elias in the West, Machakel in the Northwest, Sinan in the North, Aneded and Debay Tilatgin in the East (GDLFDO 2017).

The study kebeles, namely Aba Libanos, Yebona Erjina, Wenka and Addisna Gulet from midland(Woinadega) agro-ecology zone has 2011,2246,2292 and 2280 meters above sea level respectively. Chimit from lowland (Kolla) and Yebokla from highland (Dega) agro-ecological zone have 1413 and 2570 meters above sea level respectively.

\section{Data Types, Sources, Analysis and Laboratory Analysis}

The primary data were obtained through a semi structured questionnaire from the main actors in the honey value chain which includes the honey producers, honey traders, tej breweries and honey cooperatives.Secondary data were obtained from reports of different Zonal and Regional Office like livestock and fishery development, trade industry and market development, Ethiopian Revenue and Custom Authority (ERCA), and other published and unpublished materials.

A total of 22 honey samples (18 samples from six kebeles representing the three beehive types across the three agro-ecologies and 4 samples from market points) were collected and analyzed at Holleta Bee Research Center and Bless Agri Food Laboratory Services PLC (List of appendix figure 1). The survey data were analyzed using SPSS version 23

\section{RESULTS AND DISCUSSION}

\section{Beekeeping in the Study Area}

In the study area, beekeeping is dominated by traditional production system.Three types of beehives were commonly used for honey production that includes includes local (traditional hive), transitional (KTB) and frame hives.

Table 1.Honeybee Colonies in the Study Area

\begin{tabular}{lcc}
\hline Variables & $\mathrm{N}$ & $\%$ \\
\hline Traditional hives only & 64 & 53.3 \\
Traditional,Transitional and Frame hives & 5 & 4.2 \\
Traditional and Transitional hives & 26 & 21.7 \\
Traditional and Frame hives & 20 & 16.7 \\
Transitional and Frame hives & 5 & 4.2 \\
\hline Source:
\end{tabular}

Source: Household survey 2018

According to the survey of this study, the respondents' managed their colonies in their back yard (54.2\%), eave of the house $(41.7 \%)$ and inside the house $(4.2 \%)$. The placement of the beehives near the beekeepers homestead enables them to follow up the colonies, ease of inspection and management.

About $95.83 \%$ of the respondents in the study area managed traditional beehives whereas only five beekeepers (4.2\%) managed the three types of beehives (traditional transitional and frame) for honey production.Similarily, $21.7 \%$ and $16.7 \%$ of the beekeepers managed tradidtional and transitional and also traditional and frame hives respectively (Table 1). This indicates that improved beekeeping, both (KTBH and frame hive) are relatively practiced in the study area which might be attributed to due attention of the government for honey production, and extension services provided in relation with improved technologies.Hence, it would be better if GOs and NGOs could intervene in the introduction and dissemination of these improved technologies.

Table 2.Colony Holding size and Honey Productivity (kg/hive/harvest) (2012/3-2016/17)

\begin{tabular}{|c|c|c|c|c|c|c|}
\hline \multirow{2}{*}{ Years } & \multicolumn{3}{|c|}{ Colony holding(Mean \pm SE) } & \multicolumn{3}{|c|}{ Honey yield(kg/hive/harvest), (Mean \pm SE) } \\
\hline & Traditional & Transitional & Frame & Traditional & Transitional & Frame \\
\hline $2012 / 13$ & $4.2^{\mathrm{a}} \pm 0.35$ & $1.0^{\mathrm{a}} \pm 0.05$ & $1.5^{\mathrm{a}} \pm 10.7$ & $3.27^{\mathrm{a}} \pm 0.15$ & $10.0^{\mathrm{a}} \pm 1.33$ & $13.0^{\mathrm{a}} \pm 0.86$ \\
\hline $2013 / 14$ & $5.1^{\mathrm{a}} \pm 0.34$ & $1.0 \mathrm{a} \pm 0.05$ & $1.16^{\mathrm{a}} \pm 0.5$ & $3.36^{\mathrm{a}} \pm 0.15$ & $9.0^{\mathrm{a}} \pm 1.33$ & $14.6^{\mathrm{a}} \pm 0.77$ \\
\hline $2014 / 15$ & $5.4^{\mathrm{a}} \pm 0.34$ & $1.0 \mathrm{a} \pm 0.05$ & $1.33^{\mathrm{a}} \pm 0.7$ & $3.29^{\mathrm{a}} \pm 0.15$ & $8.0^{\mathrm{a}} \pm 1.33$ & $12.5^{\mathrm{a}} \pm 0.35$ \\
\hline $2015 / 16$ & $6.2^{\mathrm{a}} \pm 0.33$ & $1.0 \mathrm{a} \pm 0.03$ & $1.77^{\mathrm{a}} \pm 0.8$ & $3.31^{\mathrm{a}} \pm 0.15$ & $9.3^{\mathrm{a}} \pm 0.68$ & $14.9^{\mathrm{b}} \pm 0.43$ \\
\hline $2016 / 17$ & $6.6^{\mathrm{a}} \pm 0.33$ & $1.0 \mathrm{a} \pm 0.02$ & $1.94^{\mathrm{a}} \pm 0.9$ & $3.51^{\mathrm{a}} \pm 0.0 .15$ & $8.2^{\mathrm{a}} \pm 0.49$ & $15.1^{\mathrm{b}} \pm 0.42$ \\
\hline
\end{tabular}

Columns having different superscripts ( $a$ and $b$ ) are significantly different at $\mathrm{p}<0.05$ 
The result of this study revealed that there is a difference in the mean colony holding size between years for traditional and frame hive showing an increasing trend. But, the volume of honey harvested per hive shows fluctuation from year to year which might be due to draught and honeybee feed scarcity. The colony holding from year to year fluctuates with in hive types but the difference is not significant at $(\mathrm{P}>0.05)$. There is also a difference in the mean honey yield with in hive types from year to year but the difference is not significant at $(\mathrm{P}>0.05)$. However, the difference in mean honey yield is significant at $(\mathrm{P}<0.05)$ in frame hive in 2015/16 and 2016/17. This significance difference in honey yield may be attributed to the difference in weather condition, better florall resource and management colony (Table 3).

Table 3.Honeybee Colony Holding and Honey Productivity (kg/hive/harvest) with AEZ

\begin{tabular}{cccc|ccc}
\hline \multirow{2}{*}{ AEZ } & \multicolumn{2}{c}{ Colony holding in AEZ(Mean \pm SE) } & \multicolumn{3}{c}{ Honey /hive/harvest in AEZ(Mean \pm SE) } \\
\cline { 2 - 7 } & Traditional & Transitional & Frame & Traditional & Transitional & Frame \\
\hline Mid land & $5.41^{\mathrm{a}} \pm 0.15$ & $1.0^{\mathrm{a}} \pm 0.03$ & $1.84^{\mathrm{a}} \pm 0.6$ & $3.49^{\mathrm{a}} \pm 0.07$ & $8.75^{\mathrm{a}} \pm 0.53$ & $14.31^{\mathrm{a}} \pm 0.28$ \\
High land & $5.13^{\mathrm{a}} \pm 0.29$ & $1.0^{\mathrm{a}} \pm 0.07$ & $1.13^{\mathrm{a}} \pm 0.05$ & $3.2^{\mathrm{a}} \pm 0.13$ & $8.67^{\mathrm{a}} \pm 0.7$ & $13.5^{\mathrm{a}} \pm 0.38$ \\
Low land & $5.96^{\mathrm{b}} \pm 0.31$ & $1.0^{\mathrm{a}} \pm 0.09$ & $1.54^{\mathrm{a}} \pm 0.8$ & $3.96^{\mathrm{a}} \pm 14$ & $9.2^{\mathrm{a}} \pm 0.82$ & $15.8^{\mathrm{a}} \pm 0.49$
\end{tabular}

Columns having different superscripts ( $\mathrm{a}$ and $\mathrm{b}$ ) are significantly different at $\mathrm{p}<0.05$

Based on our study result revealed on Table 6 , the mean honeybee colony holding size and mean annual honey productivity ( $\mathrm{kg} /$ hive/harvest) in traditional beehives is highest with mean colony holding size(5.96) and mean annual honey yield of ( $3.96 \mathrm{~kg} / \mathrm{hive})$ in lowland areas.

The mean colony holding size in traditional beehives is significantly high in lowland at $(\mathrm{p}<0.05)$. But, the honey $(\mathrm{kg} /$ hive/harvest) is not significantly different at $(\mathrm{p}>0.05)$ with in hive types at different locations (Table 3). The different in the mean annual honey yield between hives might be attributed to the the productivity potential difference between hive types (higher yield per hive for improved hives). Similarily, the difference in honey yield with in hive types at different location might be attributed to the suitability of weather condition and availability of floral resources. The study conducted by Bekele (2015) in Bale zone aligned with this research finding that indicated that the mean honeybee colony holding of traditional beehives in Dellomena (Kolla) was significantly higher $(\mathrm{p}<0.05)$ than that of Adaba (Woina-dega) and Dinsho (Dega) agro-ecology.

\section{Honey Pre and Post-Harvest Management Practices Honey pre-harvest practices Colony inspection}

Apiary management and colony inspections are considered to be among the most important practices undertaken by beekeepers. Out of the total respondents, $47.5 \%, 35 \%, 15 \%$ and $2.5 \%$ are found to perform external inspection every three days, once a week, once in two weeks and once in a month respectively (Table 4.).Beekeepers inspect their apiary sites to safe guard the colonies from ants and other insect pests. They inspected their colonies for the purpose of honey harvesting, colony conditions and management practices. A similar study conducted by Bekele (2015) that external colony insepection frequency was everyday $(8.9 \%)$,every three days $(12.2 \%)$, every week $(7.2 \%)$, every two weeks $(8.9 \%)$, every month $(36.1 \%)$, not at all $(10.6 \%)$ and if necessary $(16.1 \%)$.

Table 4.Pre-harvest Handling of Honey

\begin{tabular}{|c|c|c|c|}
\hline Pre-harvesting variables & Response variables & $\mathrm{N}$ & $\%$ \\
\hline \multirow{4}{*}{ Frequency of honey harvest } & Once a year & 75 & 62.5 \\
\hline & Twice a year & 33 & 27.5 \\
\hline & Three times a year & 12 & 10 \\
\hline & Every three days & 57 & 47.5 \\
\hline \multirow{3}{*}{ Frequency of colony inspection(external) } & Once a week & 42 & 35 \\
\hline & Once in two weeks & 18 & 15 \\
\hline & Once in a month & 3 & 2.5 \\
\hline \multirow[t]{2}{*}{ How often do you replace old combs } & Twice a year & 49 & 44.5 \\
\hline & Every one year & 61 & 55.5 \\
\hline \multirow{4}{*}{ Feed resources to young colonies } & Bee forage & 30 & 44.8 \\
\hline & Water, Pea flour and Pepper & 23 & 34.3 \\
\hline & Honey & 5 & 7.5 \\
\hline & Sugar syrup & 9 & 13.4 \\
\hline
\end{tabular}

\section{Feeding honeybees}

Though honeybees are storing honey for their own consumption, honey producers are harvesting all the honey in a way that honeybees are exposed to feed shortage.Regarding to colony feeding, our result has revealed that $55.8 \%$ of the respondents are providing additional feeds to their colonies during dearth periods.Among the respondents who were providing additional feeds to colonies during dearth period, $44.8 \%$ have planted bee forage plants, $34.3 \%$ have provided water, bean flour, and pepper powder, $13.4 \%$ provided sugar and $7.5 \%$ have provided honey (Table 
4).

\section{Agro-chemical application}

The most common crops grown in the study district includes teff, wheat, maize and barely. Agro-chemicals (like 2-4-D, Malathion and DDT) are among those which are used to control crop weeds and pests.However, misuse of these agro-chemicals is directly to affect the health status of honeybess and indirectly quality of honey.Ingeneral, as a result of unplanned agro-chemical application, honeybee colonies either die out or abandon their hives and environment.According to our result, the majority of respondents ( $89.2 \%)$ have been found to use agro-chemicals in the study area for different reasons being control of crop weeds and and pests is the priority one.

Table 5.Agro-chemical Application and Smoking Practice

\begin{tabular}{llrr}
\hline Variables & Response variables & $\mathrm{N}$ & $\%$ \\
\hline \multirow{2}{*}{ Did you use agro chemicals } & Yes & 107 & 89.2 \\
& No & 13 & 10.8 \\
Measures taken to protect your colonies from & I never know & 25 & 20.8 \\
agrochemical & Bees mgt at beekeepers level & 29 & 24.2 \\
& Legislative measures at administrative level & 7 & 5.8 \\
Did you use smoking while harvesting honey & Communicating farmers using chemicals & 59 & 49.2 \\
& Yes & 108 & 90 \\
& No & 12 & 10 \\
\hline
\end{tabular}

Regarding critical measures taken taken to protect honeybee colonies from side effect of agro-chmicals, $49.2 \%, 24.2 \%$ and $5.8 \%$ of the respondents have tried to communicate withagro-chemmical users on proper application through time management, have used different management measures during chemical application and used legislative measures at administrative levels.However, the remaining $20.8 \%$ of the respondents never know how they could protect their colonies from side effect of mismanaged agro-chemicals (Table 5).

\section{Honey harvesting and handling}

Respondents in the study area harvested honey once (62.5\%), twice $(27.5 \%)$, and three times a year $(10 \%)$.This study was in line with the findings of Atsbaha (2015) which showed $66.7 \%$ and $33.3 \%$ of the rspondents harvested honey once and twice a year respectively.Honey harvesting frequency might vary due to availability of honeybee forage and seasonal suitability.Furthermore, respondents ingeneral, are using water and smoking during transferring, honey harvesting and when performing other management activities.

Specifiically, the majority (90\%) of the respondents, during honey harvesting, were using smoking and the remaining $(10 \%)$ did not rather sprinkling of water.Corncob ("Quorekonda") and dried animal dung ("Kubet") were selected as the most common types of smoking materials in beekeeping.The reasons for using these techiniques is to tame and push away the honeybees while managing. The smoking might have a side effect on the quality as honey has a hygroscopic nature.This might be attributed to changing the colour, odour and tastes of honey.The study conducted by Bekele (2015) was not in line with our result showing the most common smoking materials used in Bale Zone were known to be Juniperus procera, old clot and Hasufe.

\section{Honey post- harvest practices}

Honey storage and processing

Quality of honey is quite sensitive parameter not only during harvesting and semi-processing but also during storage, packaging and transportation. Our result showed that the majority (83.3\%) of the respondents did not strain honey afer harvesting while $16.7 \%$ of them did straining. Among the most common reasons for not straining honey, $69 \%, 17 \%, 11 \%$ and $3 \%$ of the respondents from those who were straining honey believed that it is due to buyers' preference, lack of know how, lack of extracting materials and decrease in volume after straining respectively(Table 6).

Table 6.Honey Straining and Extraction Practice

\begin{tabular}{llll}
\hline Honey harvesting variables & Response variables & N & $\%$ \\
\hline Do you strain (extract honey) & Yes & 20 & 16.7 \\
& No & 100 & 83.3 \\
Reasons not to extract honey & Lack of straining materials & 11 & 11 \\
& Lack of know how & 17 & 17 \\
& The buyers do not prefer it & 69 & 69 \\
& The volume of honey will decrease & 3 & 3 \\
\hline
\end{tabular}

In general, the majority of the respondents in the study area are storing honey for a short period of time. However, $28.3 \%$ of them divulge honey immediately after harvest due to their immediate need for money $(61.8 \%)$ and wastage of by families $(38.2 \%)$. About $55.8 \%$ of the respondents stored honey for less than one month, of 
which $28.3 \%$ stored honey for about two weeks. The remaining $13.3 \%$ and $2.5 \%$ stored honey from $1-6$ months and 7-12 months respectively. Different reasons like honey price increase some times after harvest (93\%) and lack of transportation (3.5\%) especially during rainy season were mentioned to be the major reasons to store honey. The remaining .5\% replied as the beekeepers were interested to give for friends/ relatives.

Concerning the storage and transportation materials, about $49.2 \%, 39.2 \%$ and $11.6 \%$ of the respondents used plastic baldi \& fertilizer bags, only plastic baldi and fertilizer bags respectively (Table 7).A study conducted by Tezera (2013), Lasta Woreda of North Wollo Zone, has reported a different result.According to his result, erthen pot $(51 \%)$, guard $(40 \%)$ and plastic containers $(5 \%)$ were used as storage and transportation materials. This indicates fertilizer bags are appropriate materials to keep honey at its desired qualityduring storage and transportation.

Table 7.Honey Storage Practice

\begin{tabular}{|c|c|c|c|}
\hline Storage variables & Response variables & $\mathrm{N}$ & $\%$ \\
\hline \multirow{5}{*}{ How long do you store honey } & Never store & 34 & 28.3 \\
\hline & For about two weeks & 34 & 28.3 \\
\hline & Less than 1 month & 33 & 27.5 \\
\hline & $1-6$ months & 16 & 13.3 \\
\hline & 7-12 months & 3 & 2.5 \\
\hline \multirow{3}{*}{$\begin{array}{l}\text { Storage /transportation materials } \\
\text { (containers) }\end{array}$} & Plastic Baldi & 47 & 39.2 \\
\hline & Fertilizer bags & 14 & 11.6 \\
\hline & Plastic Baldi and bag & 59 & 49.2 \\
\hline \multirow[t]{2}{*}{ Reasons for storing honey } & The price will be increased & 80 & 93 \\
\hline & Lack of transportation & 3 & 3.5 \\
\hline \multirow{3}{*}{ Reasons for not storing honey } & I want to give for friend and relatives & 3 & 3.5 \\
\hline & to sell soon and use the money & 73 & 61.8 \\
\hline & $\begin{array}{l}\text { If I store, it will be wasted by families and } \\
\text { relatives }\end{array}$ & 13 & 38.2 \\
\hline
\end{tabular}

Table 8.Physico chemical Properties of Honey with Hive Types

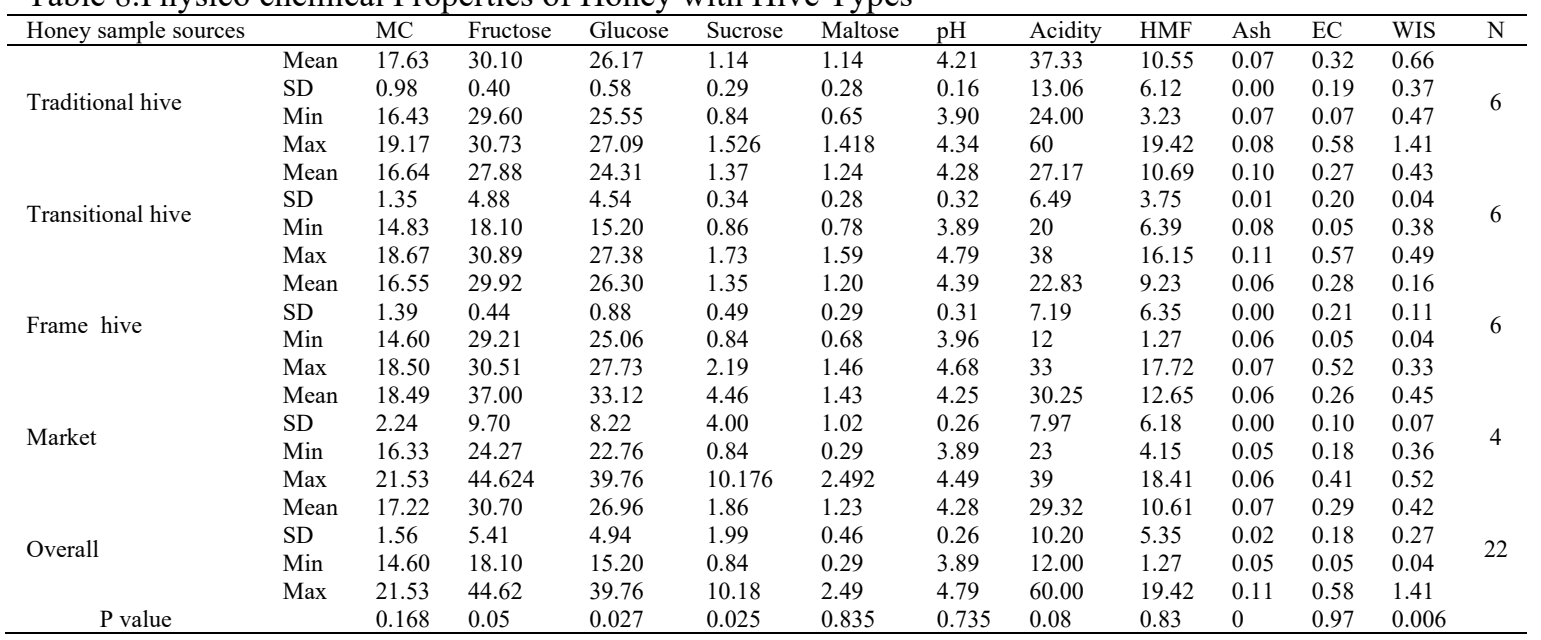

EC-Electric Conductivity, HMF-Hydroxymethylfurfural, MC-Moisture content,, WIS-Water Insoluble Solids Source: Sample laboratory result, 2018

The higher the value of the acidity in honey, the higher will be its antimicrobial property. Two honey samples $(9.1 \%)$, both from traditional beehives were having 44 and $60 \mathrm{meq} \mathrm{acid} / \mathrm{kg}$, both had acidity higher than the national standards (40 meq acid/ $\mathrm{kg}$ ) and only one honey sample from highland areas had mean acid value above the international standard limits $(50 \mathrm{meq} \mathrm{acid} / \mathrm{kg})$. The remaining 20 honey samples $(90.9 \%)$ had mean acidity value ranging between 39 and 12 which is in the range) indicating the freshness of the honey samples. The mean acidity value from three types of hive was not significantly different at $(\mathrm{P}>0.05)$ whereas the mean acidity value of honey samples from highland was significantly different at $(\mathrm{P}<0.05)$ than the other locations(Table 8). The variation might have been observed due to the different floral sources in different agro ecologies in the study district.

The $\mathrm{pH}$ value ranged from 3.89 to 4.79 with mean values of 4.28 and SD value of 0.26 and this result is close to other findings Tessega (2009) and Tewodros (2010) honey sample with a pH range of 3.49 to 5.58 and 3.55 to 4.75 respectively. The $\mathrm{pH}$ of honey samples from frame hives was numerically higher than transitional and traditional beehives but was not significantly different at $(\mathrm{P}>0.05)$ whereas honey samples from midland agro- 
ecology had higher mean $\mathrm{pH}$ value than others and there has been a significant difference at $(\mathrm{P}<0.05)$ in the mean $\mathrm{pH}$ value of honey samples from different locations. Even though no Ethiopian standard for $\mathrm{pH}$, the result of this study is close to other reports and indicated that the low $\mathrm{pH}$ of the honey samples inhibit the presence and growth of microorganisms and has great importance during storage and shelf life of honey.

The water-insoluble solid for the honey samples collected from the study area had a mean value of 0.412 and SD value of 0.27 which is below the national standard $(0.5 \%)$ while the mean value for traditional beehives and market points was higher than the samples collected from other hive types. The water insoluble content of honey from traditional hives was significantly higher $(\mathrm{P}<0.05)$ than honey samples from improved and market points could be due to poor honey harvesting and handling practice and presence of honey water- insoluble solids like beeswax, pollen, honey comb and other debris.

Table 9.Physico chemical Properties of Honey Across agro-ecological Zones

\begin{tabular}{|c|c|c|c|c|c|c|c|c|c|c|c|c|c|}
\hline AEZ & & $\mathrm{MC}$ & Fructose & Glucose & Sucrose & Maltose & $\mathrm{pH}$ & Acidity & HMF & Ash & $\mathrm{EC}$ & WIS & $\mathrm{N}$ \\
\hline \multirow{4}{*}{ Midland } & Mean & 16.82 & 28.89 & 25.24 & 1.20 & 1.17 & 4.43 & 27.25 & 11.00 & 0.08 & 0.36 & 0.35 & 12 \\
\hline & SD & 0.81 & 3.47 & 3.28 & 0.35 & 0.32 & 0.19 & 8.20 & 4.89 & 0.02 & 0.16 & 0.19 & \\
\hline & Min & 15.53 & 18.10 & 15.20 & 0.84 & 0.65 & 4.22 & 12.00 & 5.11 & 0.06 & 0.07 & 0.04 & \\
\hline & Max & 18.00 & 30.89 & 27.73 & 1.73 & 1.589 & 4.79 & 44.00 & 19.42 & 0.11 & 0.58 & 0.52 & \\
\hline \multirow{4}{*}{ Highland } & Mean & 18.78 & 30.40 & 26.37 & 1.61 & 1.27 & 3.95 & 43.67 & 9.52 & 0.08 & 0.07 & 0.39 & 3 \\
\hline & SD & 0.35 & 0.29 & 0.14 & 0.54 & 0.19 & 0.05 & 14.36 & 7.57 & 0.02 & 0.02 & 0.18 & \\
\hline & Min & 18.5 & 30.21 & 26.281 & 1.111 & 1.079 & 3.9 & 33 & 1.272 & 0.067 & 0.07 & 0.22 & \\
\hline & Max & 19.17 & 30.73 & 26.534 & 2.191 & 1.458 & 4 & 60 & 16.15 & 0.102 & 0.58 & 0.57 & \\
\hline \multirow{4}{*}{ Lowland } & Mean & 15.59 & 29.85 & 26.24 & 1.31 & 1.22 & 4.08 & 22.00 & 7.45 & 0.07 & 0.24 & 0.71 & 3 \\
\hline & SD & 1.51 & 0.07 & 0.38 & 0.11 & 0.08 & 0.21 & 1.73 & 5.39 & 0.01 & 0.25 & 0.61 & \\
\hline & Min & 14.60 & 29.78 & 25.83 & 1.21 & 1.13 & 3.89 & 21.00 & 3.23 & 0.06 & 0.05 & 0.33 & \\
\hline & Max & 17.33 & 29.93 & 26.58 & 1.43 & 1.29 & 4.31 & 24.00 & 13.52 & 0.08 & 0.52 & 1.41 & \\
\hline \multirow{4}{*}{ Market } & Mean & 18.49 & 37.00 & 33.12 & 4.46 & 1.43 & 4.25 & 30.25 & 12.65 & 0.06 & 0.26 & 0.45 & 4 \\
\hline & $\mathrm{SD}$ & 2.24 & 9.70 & 8.22 & 4.00 & 1.02 & 0.26 & 7.97 & 6.18 & 0.00 & 0.10 & 0.07 & \\
\hline & Min & 16.33 & 24.27 & 22.76 & 0.84 & 0.29 & 3.89 & 23.00 & 4.15 & 0.05 & 0.18 & 0.36 & \\
\hline & Max & 21.53 & 44.62 & 39.76 & 10.18 & 2.49 & 4.49 & 39.00 & 18.41 & 0.06 & 0.41 & 0.52 & \\
\hline \multirow{4}{*}{ Over all } & Mean & 17.22 & 30.70 & 26.96 & 1.86 & 1.17 & 4.28 & 29.32 & 10.61 & 0.07 & 0.29 & 0.42 & 22 \\
\hline & SD & 1.56 & 5.41 & 4.94 & 1.99 & 0.32 & 0.26 & 10.20 & 5.35 & 0.02 & 0.18 & 0.27 & \\
\hline & Min & 14.60 & 18.10 & 15.20 & 0.84 & 0.29 & 3.89 & 12.00 & 1.27 & 0.05 & 0.05 & 0.04 & \\
\hline & Max & 21.53 & 44.62 & 39.76 & 10.18 & 2.49 & 4.79 & 60.00 & 19.42 & 0.11 & 0.58 & 1.41 & \\
\hline $\mathrm{p}$ value & & 0.009 & 0.063 & 0.036 & 0.024 & 0.846 & 0.006 & 0.031 & 0.644 & 0.113 & 0.059 & 0.23 & \\
\hline
\end{tabular}

EC-Electric Conductivity, HMF-Hydroxymethylfurfural, MC-Moisture content, WIS-Water insoluble Solids Source: Sample laboratory result, 2018

The electric conductivity (EC) of the honey samples collected from the study area varied from 0.05 to 0.58 with mean value of 0.29 and SD value of 0.18 and the result was below the national standard which is 0.8 (Table 9).Like $\mathrm{pH}$, ash and acid contained in honey, EC was highest in honey samples from traditional beehives from midland area.The mean EC value of honey was not significantly different $(\mathrm{P}>0.05)$ between the three types of beehives across the three agro-ecologies.

Hydroxymethylfurfural (HMF) is one of the most commonly used parameter for determining the honey freshness. The amount of HMF in honey is one of the important indicators of honey quality. In fresh honey, HMF is present only in trace amounts and its concentration increases with storage and prolonged heating of honey (Bogdanov 2011).It is one of the important indicators of honey whether it is over heated, aged or adulterated with invert sugar (hydrolyzed sucrose). The mean HMF value of all samples collected from the three types of beehives across the three locations was within the range of the national and international standards which is below $40 \mathrm{mg} / \mathrm{kg}$ of honey and no significance difference $(\mathrm{P}>0.05)$ was observedbetween different beehive types across the three agr-ecologies. The low HMF content in the study area indicated that the honey was fresh (comb honey supplied to the market immediately after harvest) and good handling practice.

Sugars are the main constituents of honey comprising about $95 \%$ of honey dry weight (Bogdanov 2011). The sugars of honey are responsible for many of the physicochemical properties such as viscosity, hygroscopic and granulation characteristics of honey.In the study area, the overall mean value of fructose, glucose, sucrose and maltose content of honey was $(30.7 \pm 5.41),(26.96 \pm 4.94),(1.86 \pm 0.99)$ and $(1.23 \pm 0.46) / 100 \mathrm{~g}$ respectively. In all the honey samples, the fructose content is higher than the glucose content.

The maximum mean value of fructose, glucose, sucrose and maltose was also found to be 44.6239 .76 , 10.18and 2.49 respectively for honey samples obtained from market points, particularly from honey retailers who have a trade license of both butter and honey together. The sucrose content of honey samples from the honey retailers $(10.18 \%)$ was higher than the national and international standards with maximum value $(5 \%$ or $\mathrm{g} / 100 \mathrm{~g})$. This high sucrose content in honey samples from those retailers could suggest an addition of sugar in the honey and this was in line with the roamers of the consumers about the adulteration of honey by the retailers. The fructose and maltose content of honey samples was not significantly different at $(\mathrm{P}>0.05)$ both between the three hive types and locations whereas the sucrose and glucose content of the honey samples was significantly different at $(\mathrm{P}<0.05)$ both in between hive types and among different locations. 


\section{CONCLUSION AND RECOMMENDATIONS}

The low productivity per hive for traditional (3.51 \pm 0.51$)$ than transitional $(8.2 \pm 0.49)$ and frame $(15.1 \pm 0.42)$ hives, the government and other responsible bodies should focus in increasing the production and productivity of honeybee hive through improved management and use of improved bee hives, developing integrated strategy which enables beekeepers minimize the effects of agrochemicals on honeybee colonies and honey quality (use of agrochemicals which are not harmful to honeybee colonies and proper application that does not match with flowering periods).

The result of the laboratory analysis of honey quality revealed that the mean values of moisture content, glucose, sucrose, $\mathrm{pH}$ and acidity of honey were significantly different among different locaiosns $(\mathrm{P}<0.05)$. Similarliy, the mean values glocuse, sucrose, ash and water insoluble solids were significantly differerent at $(\mathrm{P}<0.05)$ between the three types of production system. In general, the honey samples collected from the market points particularily from honey traders were with high sucrose level $(10.18 \%)$ confirming the adulteration of honey with sugar syrups and as a result inspection, control, and regulatory measures are indispensable tasks to improve the quality of honey in the study area.

\section{ACKNOLOGEMENT}

I am grateful to different offices of East Gojjam Zone for giving me relevant secondary data mainly Gozamin Livestock and Fishery Development Office.In addition, my thanks goes to Holleta Bee Research Center and Bless Agri Food Laboratory Services PLC for their support in laboratory analysis

Most importantly, I would like to express my heartfelt thanks for my wife, Simegn Ketema, our first born baby Markonal Sileshi and also to Maranata Ketema for their patience and encouragements. The last but not least thank goes to to my brothers, Semahegn and Melkamu for their moral support and advice during my study.

\section{References}

Abera Belay, Gulelat Desse Haki, Marc Birringer, Hannelore Borck, YoungChul Lee, Chang-Won Cho, KyungTack Kim, and Bikila Bayissa, Kaleab Baye \& Samuel Melaku (2016): Sugar profile and physicochemical properties of Ethiopian monofloral honey, International Journal of Food Properties, DOI: 10.1080/10942912.2016.1255898 http://dx.doi.org/10.1080/10942912.2016.1255898

Bogdanov, S. (2011). Royal Jelly, Bee Brood: Composition, Health, Medicine: A Review. In Bee Product Science(pp. 1-35).

Codex Alimentarius Commission, 2001. Revised Codex Standard for Honey. Codex Standard 12-1981,Rev.1 (1987), Rev.2.2001. Joint FAO/WHO Food StandardsProgramme. 24th Session, FAO Headquarters, Rome, Italy.

CSA. 2016/17. Agricultural Sample Survey 2016/17 [ 2009 E.C.] volume II: Report on Livestock and Livestock Characteristics (Private Peasant Holdings). In Statistical Buletin 573 (Vol. II). Addis Ababa, Ethiopia: Central Statistical Agency (CSA), Federal Democratic Republic of Ethiopia

Desalegn Begna. 2015. Assessment of Pesticides Use and its Economic Impact on the Apiculture Subsector in Selected Districts of Amhara Region, Ethiopia. Environmental \& Analytical Toxicology, 5(2), 2-5. doi:10.4172/2161-0525.1000267.

ERCA. 2008-2016. Ethiopian Revenue and Custom Authority. Annual Report on Honey Export, Addis Ababa, Ethiopia.

Ethiopian Standarsds Agency. 2013. Ethiopian honey quality and standard (ES 1202:2013), Addis Ababa, Ethiopia.

GDLFDO.2009.(Gozamen District Livestock and Fishery Development Office). Annual Report.Gozamen.Ethiopia.

Nuru Adgaba. 2002. Geographical races of the Honeybees (Apis mellifera L.) of the Northern Regions of Ethiopia. Ph.D dissertation. Rhodes University, South Africa.

Tessega Belie. 2009. Honeybee production and marketing systems: Constraints and opportunities in Burie District of Amhara Region, Ethiopia. Dissertation for Award of MSc Degree at Bahir Dar University, Ethiopia. Bahirdar University, Department of Animal Science and Technology. MSc Thesis. 


\section{List of Appendix}

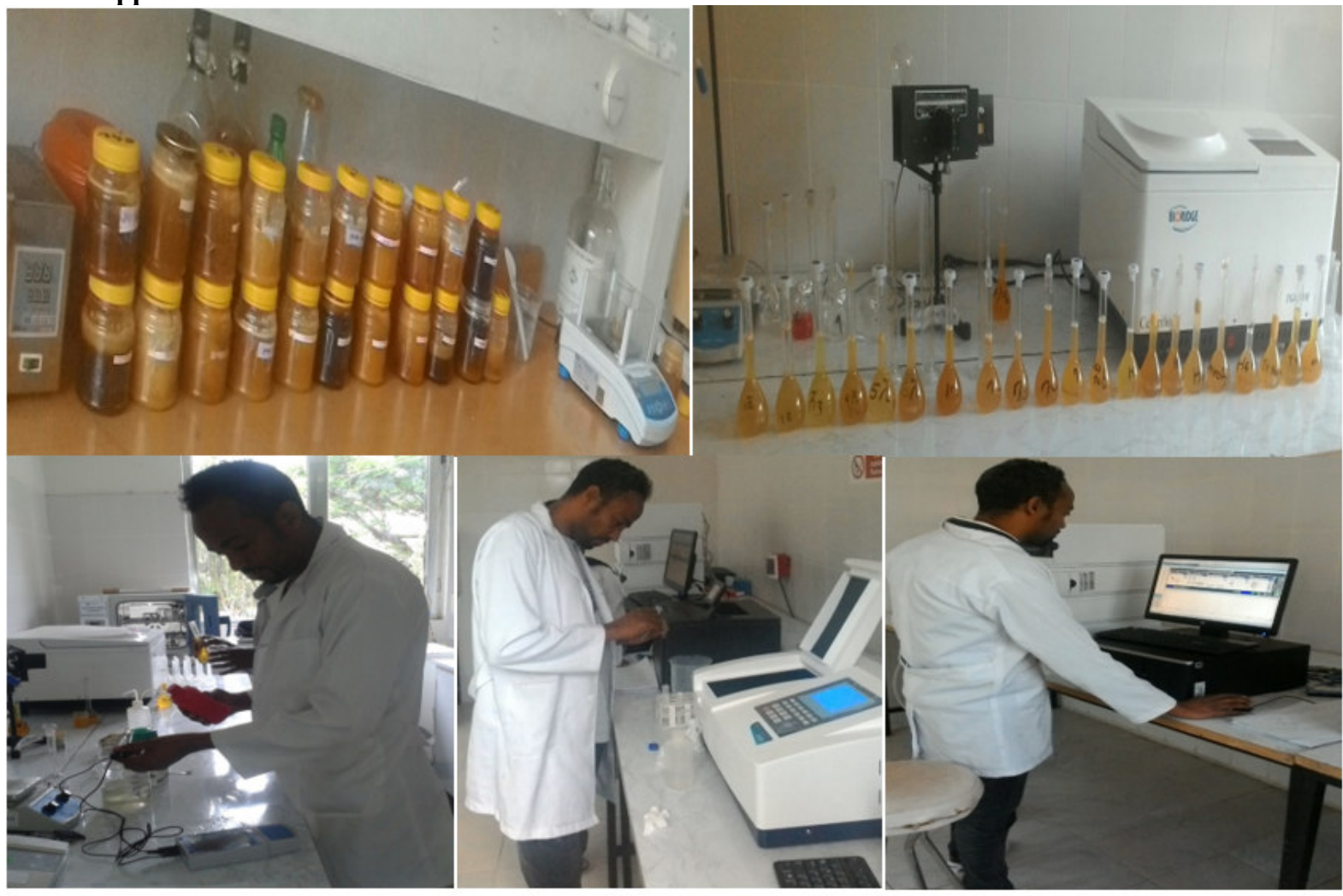

Lists of Appendix Figures 1. Honey Quality and Laboratory Analysis
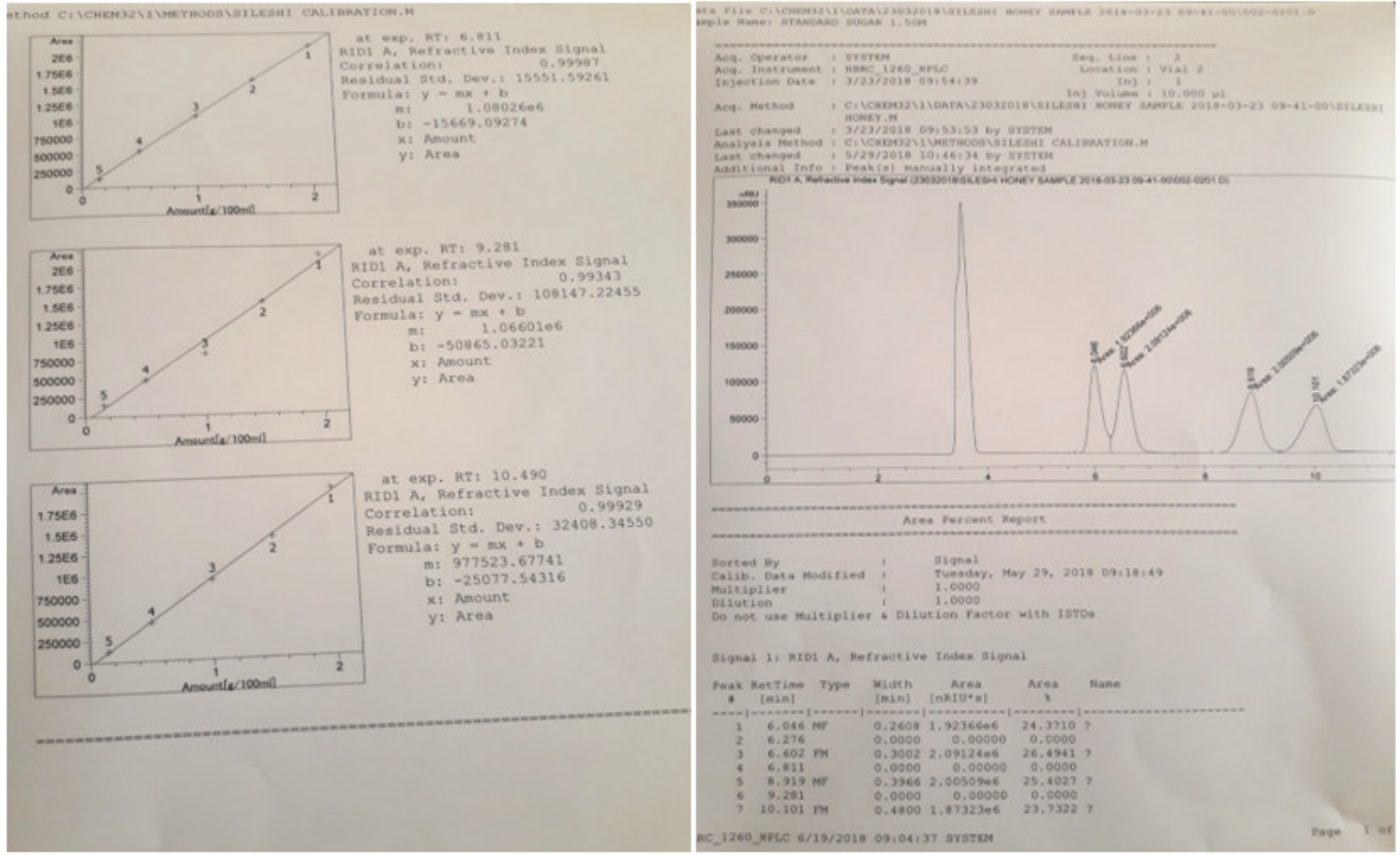

Lists of Appendix Figures 2.Calibration of HPLC for Honey Sugars 